Article

\title{
The War on Concepts: The Thought of Jan Patočka and the War on Terror
}

Katy Scrogin

A long with the notion of war in general, the so-called war on terror has been, since its inception in 2001, the subject of much debate and theorization. French thinker Gilles Andréani discusses the appropriateness of the term "war" to apply to the present conflict; ${ }^{1}$ Antonio Negri has argued how the State's use of the concept of peace justifies its engagement in warfare in general..$^{2} \mathrm{I}$ approach the conversation, however, by presenting the thoughts of $20^{\text {th }}$ century Czech philosopher Jan Patočka on the relationship between war and peace. Here, I utilize his views, formulated in the context of Soviet control of Eastern Europe, to deconstruct the Bush administration's declaration of war on a concept; in this case, terror. In what follows, I delineate the main aspects of Patočka's understanding of continuous warfare in the $20^{\text {th }}$ century, after which I apply them to some of the central features of the Bush administration's war rhetoric. Additionally, I suggest that Patočka's notion of the solidarity of the shaken may provide a starting point from which all of those involved in the conflict may begin to move forward.

Patočka's thoughts on war entail some basic concepts, especially those of light (or the day) and darkness (or the night). Both are essential aspects of human life; night represents the mystery and uncertainty inherent in human existence, the inability to offer complete or systematic accounts of, or prescriptions for, reality. It is only out of this realm of darkness, Patočka says, that any knowledge - any light or clarity - emerges. It is not simply that the night is a mere absence of light; rather, the night contains being and value of its own. The significance of asserting that light emerges out of darkness, then, is that, only through engagement with - not avoidance of - this mystery, with its uncertainty, questions, and problems, does any sort of understanding about our existence come forth. Finding "meaning" in life is not a matter of liberating ourselves from darkness and of finding absolute answers; rather, making sense of our being is entailed in the very quest for that sense, in our confrontation with the night.

Such engagement does not entail a simple glorification of the darkness. Rather, in searching for meaning in our lives, Patočka wants to emphasize that

1 See Gilles Andréani, "The 'War on Terror': Good Cause, Wrong Concept," in Survival 46 (Winter 2004-05), 31-50.

2 See Antonio Negri, Time for Revolution, trans. by Matteo Mandarini (New York: Continuum, 2003). 
we are not to revel in the dark aspect of our lives. Nor, on the other hand, do we disregard or suppress it in claiming access to the light. In other words, a balance must be maintained wherein both "sides" are allowed interplay with each other, not forced into unnatural stasis; wherein a critical engagement with our existence and its inherent "problematicity" does not cease during our lifetimes. ${ }^{3}$ Appropriating a notion used by Martin Heidegger, Patočka refers to this perpetual struggle as polemos, which is not, for the Czech thinker, only an intrinsic aspect of life, but is also "the primordial insight that makes philosophy possible."4

Patočka believes that the "West's" desire for easy and absolute certainty, involving no wrestling with questions or answers, began with Plato's striving for the Good, with the Greek philosopher's attempt to elevate the Good day absolutely over the demonic night. Over time, then, we have grown accustomed to life in the realm of what Patočka calls, again after Heidegger, "the everyday." 5 Here, individuals are concerned, not with finding truth or the nature of being, but in attaining and/or maintaining conflict-free security in their individual existences, rid not only of physical violence, but of difficult self-reflection and meaningful conflict in dialogue. If there can be said to be a larger significance of such existence, it is in fact "security," the elimination of risk- evident, for example, in Patočka's society in the communist government's inability to tolerate criticism or a free interplay of ideas between its citizens.

How, then, does such an attitude lead to war? In trying to suppress, in favor of a certain mode of existence, the questions that the night poses, Patočka thinks that the force behind such challenges will emerge in the only way it can: through violent outburst against the artificial and fragile certainty that a society has constructed. One society may pose "questions" to another: about resources, about cultural norms, about appropriate governance. The confrontation between the two may cause one or both of them to rethink the details, and perhaps the basis of its thought and action, answers that it has provided itself and on which that society may stand or fall. Fearing the uncertainties of change, not tolerating opposition to its security-based philosophy of life, the society must eliminate the question itself- not by dialogue, which would encourage engagement with the query, but through force and war, which, although dark in its unleashing of death, is used in order to uphold the light of certainty in society.

In this clash, light - or a stable peace - is held to be the ultimate value. At first glance, lasting peace seems like a virtuous aspiration, one whose worth it might appear foolish to deny. The implications of such a desire, however, become destructive. The achievement of an "eschatological" peace would indicate that all conflict, all questions - in short, that essential aspect of

\footnotetext{
${ }^{3}$ Edward F. Findlay, Caring for the Soul in a Postmodern Age: Politics and Phenomenology in the Thought of Jan Patocka (Albany: State University of New York Press, 2002), 9, passim.

${ }^{4}$ Jan Patočka, Heretical Essays in the Philosophy of History, trans. by Erazim Kohák and ed. by James Dodd (Chicago: Open Court, 1996), xiii.

${ }^{5}$ Patočka, op cit., 98, passim.
} 


\section{THE WAR ON CONCEPTS}

life that Patočka calls polemos - would be eliminated in one final state of certainty and security. ${ }^{6}$

The winner of such a particularly motivated war, however, is never the final victor, for in the constant movement that is life, one person's certainty is not another's; peace for one society may not include some desired aspect of security included in the victor's model, and the battle for clear answers and absolute certainty will continue indefinitely. As an inherent part of human existence, darkness, uncertainty, mystery, and the continual changes that come with them, cannot be suppressed completely, and will always emerge in our lives, whether we embrace them and engage with them, or whether we attempt to ignore them until they break forth in violent insistence on recognition. "A victorious peace" which must always guard against possible threats, says Patočka, "is an illusion in which the victor morally disintegrates." Until all sides realize that no absolute peace or security, at least in earthly human life, can ever be achieved, war and violent conflict will constitute the norm of our existence.

How, then, are we to engage with the darkness in ways that do not result in violence? Patočka makes no prescriptions, for, true to his valuation of the night, there are no absolute answers to life's continual "problems." Instead, he offers as an alternative to life in the everyday the notion of "the solidarity of the shaken," and "the front" as its catalyst. ${ }^{9}$ By no means advocating war as a "good" (for it is its occurrence that he is trying to decrease via his writing), he nevertheless makes reference to it in order to show both how one emerges into shakenness, and what that state entails.

Recalling Ernst Jünger's and Teilhard de Chardin's accounts at the front during the First World War, Patocka speaks of the experience of a soldier placed in such a situation. Faced with death and its refusal to be bound or tamed by society's values and practices, that soldier, if he is able to move beyond the initial fear of this encounter, realizes that society's mandates actually have no claim on the freedom of one's soul. No longer able to accept the assurances that society's dictates offer, still confronting the radical uncertainty of a dark, yet free universe, this individual is shaken into the knowledge that "freedom does not begin. . . after the struggle is concluded, but rather has its place precisely within it." 10 Even his former enemies are no longer his adversaries; rather, the enemy "is a fellow participant in the same situation, fellow discoverer of absolute freedom with whom agreement is possible in difference. . . Here we encounter . . . the phenomenon of 'loving those who hate us' - the solidarity of the shaken for all their contradiction and conflict." 11 No longer able to dwell in the security of his previous life, what the soldier does know is that he must live in accordance with

\footnotetext{
${ }^{6}$ Ibid., 126.

${ }^{7}$ Ibid., 127.

8 Ibid., 134, passim.

${ }^{9}$ Ibid., 125, passim.

${ }^{10}$ Ibid., 134.

${ }^{11}$ Ibid., 131.
} 
the recognition of freedom experienced in the face of death, striving for this free "agreement in difference" with other shaken individuals.

One need not undergo an actual experience at a military front in order to understand this state. Patočka assures us that there is no proper or prescribed way of coming to the same realizations that the solider did, although suffering prolonged persecution, for example, could also shatter the illusions by which an individual had been surrounded. We must remember that, not only was Patočka speaking of wars as typically defined; he was also addressing the situation in communist Czechoslovakia, where a protracted period of human rights violations had led to societal defeatism. Not until years after the philosopher's death at the hands of government police did the philosopher's shaken country finally emerge out of its bleak, totalitarian existence.

\section{The Present: Darkness and Light in the War on Terror}

If we hold American society, past or present, up to Patočka's analysis, his thoughts seem just as insightful as they were in his own situation. When we apply his reasoning to the U.S. political arena, specifically to the current Bush administration's war rhetoric, Patočka's discernment becomes all the more striking. Here, we see manifest evidence of a government obsessed with maintaining the certainty of its day, of preventing questions, intentionally threatening or not, to be posed to or about it. In the following section, I would like to use Bush's own words, as well as an analysis of The National Security Strategy of the United States, to illuminate how the administration's rhetoric provides an exemplary illustration of what is being criticized in Patočka's theory. ${ }^{12}$

In his analysis of The National Security Strategy, Douglas Ayling describes the general character of the document as "promot[ing] the idea that all the effects of misfortune can be eliminated from life- it seems to want to create a Disney World of the world, where all threats have been vanquished."'13 Such an aspiration ably demonstrates the outlook of a day-driven society to which Patočka points.

What becomes immediately evident in the strategy document is the overt assertion that current U.S. policy serves the goal, not only of combating terrorist acts, but of eliminating fear, evil, and terror altogether from the world. Instead of concentrating on specific enemies- difficult to do when one is sometimes unsure of who they are- the administration often identifies entire concepts as its foes, slating them for the impossible fate of eradication. From the

12 The White House, The National Security Strategy of the United States of America

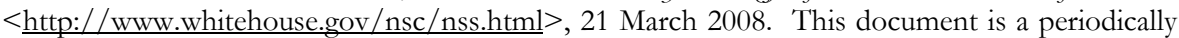
updated explanation of the ways in which the president's administration proposes confronting challenges to the security of the nation.

13 Douglas Ayling, "An Analysis of the Rhetoric and the Ideology of the National Security Strategy of the United States of America, 2002," < $<$ http://www3.nd.edu/ dayling /content/documentsAcademic/University $\% 20$ of $\% 20$ Notre $\% 20$ Dame/Ananalysisoftherhetorica ndtheideologyoftheNationalSecurity\%81c.pdf>, 21 March 2008. 


\section{THE WAR ON CONCEPTS}

beginning of this war on terror, the administration has openly maintained, according to The National Security Strategy, that it is its mission to "rid the world of evil."14 "Freedom and fear are at war," it also states, identifying the United States as the sole possessor of the former and using the sweeping term "terrorists" as the lone and shameless proponents of the latter. ${ }^{15}$ Additionally, instead of confining itself to dealing with a specific group called "terrorists," the government, via an early rallying speech by President Bush, asserts that it is undertaking a war on terror itself. ${ }^{16}$ In declaring war against concepts, the administration has essentially given itself license to continue its efforts indefinitely - for to eradicate evil, terror, and fear (or any other "dark" aspect of life that may find its way onto the blacklist) from human existence would, setting aside the impossibility of the task, leave us in a world devoid of an entire class of human emotions. After such purification, there would be, at the level of the trivial, no more horror films; at the grandiose end of the spectrum, no fear of the future or of evil deeds - and in a society without conflict, very little need for debate or discussion.

This war against concepts affects the way in which the terms used in the administration's rhetoric are presented. By allying "the U.S. side" alone to the concept of freedom, it is saying that freedom is "the American brand of freedom." If someone presents a different, equally valid variety of freedom to the United States, then the latter has no exclusive claim as owner of the concept after all, and will have a more difficult time justifying the belief that its mode of action is the only acceptable way in which to defend the idea. The unwillingness to acknowledge that other people understand concepts differently, and that they appreciate and want various things out of life- for example, different sorts of freedom, whether tribally based or founded on a system of one-person-one-vote- indicates an aversion to facing any questions those alternative views might pose, questions that could possibly cause a change of mind about a society's way of life, its ideas, and so on. As long as this fear of difference is maintained, there is no way to go about addressing questions or the existence of other understandings of life than to eradicate them. Says Ayling about The National Security Strategy, “. . . the mantra [of American-style democracy] is repeated to the exclusion of doubt, almost as if knowledge about the continued existence of differing values and cultures challenged and undermined America itself." 17

This sort of thinking in dichotomized absolutes is evident in the administration's definition of enemies and allies. Ayling states that The National Security Strategy posits "no middle ground or grey area between the friends of

14 The White House, The National Security Strategy of the United States of America, Section

3.

${ }^{15}$ Ibid.

16 The White House, "Address to a Joint Session of Congress and the American People," <http://www.whitehouse.gov/news/releases/2001/09/20010920-8.html>, April 2008. See also National Security Strategy.

${ }^{17}$ Ayling, op cit., 23. 
America and 'our enemies."'18 In a speech made to Congress in 2001, Bush asserted this sentiment even more strongly: "Every nation, in every region, now has a decision to make. Either you are with us, or you are with the terrorists." 19 Six years later, in order to justify the "troop surge," the president continued to use this divisive logic; in 2007, he maintained that the continuing struggle between the U.S. and its enemies constituted "the decisive ideological struggle of our time. On one side are those who believe in freedom and moderation. On the other side are extremists who kill the innocent, and have declared their intention to destroy our way of life."20

Thought, of course, leads to action. The black-and-white worldview that results in the creation of an "absolute adversary" is observable, for example, in soldiers' reports of their experiences in the war against terror. ${ }^{21}$ According to Geoff Millard, an Iraq War veteran,

the word "haji" [sic] is used [by military personnel] to dehumanize people not just of Iraq and Afghanistan, but anyone there who is not us. . Everyone that was not a US force became a haji, not a person, not a name, but a haji. I used to have conversations with members of my unit, and I would ask them why they use that term, especially members of my unit who are people of color. It used to shock me that they would. And their answers were very similar, almost always, and that was, "They're just hajis. Who cares?”

"And that came from ranks as low as mine, sergeant, all the way up to lieutenant colonel in my unit. The highestranking officer that I ever heard use these words was the highest-ranking officer during my deployment in Iraq: General Casey... These things start at the top, not at the bottom. ${ }^{22}$

A justifiable war demands the presence, and consequently, the immediate threat of, a clear, one-dimensional enemy. To permit any uncertainty as to whether a person qualifies as a foe or not, to allow for degrees of enemy status, weakens motivation to undertake deadly operations against him or her- for such ambiguity would cause an individual to see that could-be

\footnotetext{
18 Ibid., 7.

19 The White House, "Address to a Joint Session of Congress and the American People."

20 Voice of America, "Text of Bush Speech on Iraq," in NewsVOA.com $<$ http://www.voanews.com/english/archive/2007-01/2007-01-11voa3.cfm?CFID=291042441 \&CFTOKEN $=39965549>, 1$ April 2008.

${ }^{21}$ Patočka, op cit., 131.

22 Geoff Millard, "Testimony from Winter Soldier Hearings," in Democracynow.org $<$ http://www.democracynow.org/2008/3/18/winter_soldier_contd us_vets_active $>, 20$ March 2008.
} 


\section{THE WAR ON CONCEPTS}

enemy more as a human being and less as destruction personified. In other words, to permit questioning regarding, for example, to what extent a person is involved in "evil" activities; whether sympathy for a particular cause is evil; or whether voicing critical opposition to or reservations about any part of the war project places someone on the side of fear; constitutes an unacceptable foray into the dangerous gray area of hesitation, a journey which will surely only allow for a flood of further doubt, the undermining of the United States' efforts, and the complete victory of evil and darkness.

Not only are the results of this dichotomization visible in the reports of soldiers in the field, but the government's approval of the use of particular "enhanced interrogation techniques" also illustrates the administration's continuing attachment to the value of absolute certainty at any cost. In spite of the fact that the government is a signatory to the Geneva Convention's ban on torture, the Bush administration maintains that it is justified in allowing itself exceptions to the rules. ${ }^{23}$ "[B] elief that an attack might be imminent," according to White House deputy spokesman Tony Fratto, would constitute one of those exceptions. ${ }^{24}$ The government's admission that waterboarding, for example, has only been used against three people in the war on terror is justified, so it claims, by appeals to "the specific circumstances under which it was employed." 25 It appears that to allow questions even about the very means of achieving the government's purpose, at least in this instance, signals to it the casting of a perilous shadow upon the absolute light of a clear mission.

If we can effectively dismiss one bloc as the undifferentiated "enemy," there is no reason to consider its various griefs, aspirations, or concerns, for the manner in which it has been defined does not allow for such human possibilities. Rather, this group represents only fear, terror, evil, and danger to freedom - and as such, is deserving only of elimination. It is easy, therefore, to justify, for instance, torturing individual members of the enemy bloc.

To arrange the structure of the situation in this way, then, there is no room or reason for the administration to pause in its fervency and to consider what the United States as a nation may be doing to heighten the opposition's hostility - for the bearers of absolute freedom, in the rigid manner in which they have been defined, are incapable of any act of evil. In its rigid dichotomy of good and evil, the administration can avoid contemplation of its possible complicity in arousing resentment against itself; it can dodge consideration of the fact that other, more preferred forms of freedom may exist alongside the

\footnotetext{
${ }^{3}$ See Jim Lobe, "Bush Yields to Geneva Convention on Detainees," in Antiwar.com $<$ http://www.antiwar.com/lobe/?articleid=9663>, 21 March 2008.

24 "White House defends use of waterboarding," in MSNBC.com <http://www.msnbc.msn.com/id/23030663/>, 20 March 2008. It is interesting to note that, where confessions that emerge from a situation in which the confessee has been tortured, the information contained in such confessions is generally not reliable. See, for example, "Torture on Trial," in CommonDreams.org < http://www.commondreams.org/archive/2008/02/14/ 7055/>, 2 April 2008.

25 Joe Kay, "Bush Administration Acknowledges and Defends Use of Torture Technique," in World Socialist Website <http://www.wsws.org/articles/2008/feb2008/tortf07.shtml>, 21 March 2008.
} 
American brand of democracy, and that there are other cultures who may have no desire to be incorporated into its grand capitalist adventure.

In a speech given in 2005 to the National Endowment for Democracy, Bush made clear his unwillingness to acknowledge such issues and to move beyond artificial dichotomies. He stated that ". . . we're not facing a set of grievances that can be soothed and addressed ... No act of ours invited the rage of the killers ... Against such an enemy, there is only one effective response: We will never back down, never give in, and never accept anything less than complete victory." 26 By sidestepping all of the questions that may make a nation hesitant to push obstinately through with a particular mission, the administration's rhetoric only solidifies the polarity of tensions that it has created, increasing antipathy towards the United States and hurling all sides into a vicious circle of never-ending war.

In this brief consideration of the language and rhetoric of the Bush administration, what is strikingly plain is a logic that, in its functioning according to absolutes, seeks to eliminate all uncertainties. Evidence of such reasoning is apparent in the government's definition and application of concepts, and in its conviction thereby that it is not only indisputably justified in waging war, but that it may carry out that war by any means it deems necessary. No compromise is permitted in the situation: the nation will stop short of nothing other than absolute victory, absolute peace by its definition, and absolute freedom on its terms. Questions are not to be asked, and certainties are not to be muddied.

Even in 2007, when the president acknowledged that "It is clear that we need to change our strategy in Iraq," it was not the overall mission or the correctness of its basic assumptions that required reconsideration; rather, it was only the means of maintaining those convictions and of achieving the originally conceived goal. "Our past efforts to secure Baghdad failed for two principal reasons," he stated: "There were not enough Iraqi and American troops to secure neighborhoods that had been cleared of terrorists and insurgents. And there were too many restrictions on the troops we did have." 27 The delineated reasons for failure did not include a reassessment of what the overall mission should be, the justifications for being in Iraq, ${ }^{28}$ or how the occupied population might understand the situation.

\footnotetext{
26 The White House, "President Discusses War on Terror at National Endowment for Democracy," <http://www.whitehouse.gov/news/releases/2005/10/20051006-3.html>, 1 April 2008. Italics added.

27 George Bush, "Text of Bush Speech on Iraq," in Voice of America < http://www.voanews.com/english/2007-01-11-voa3.cfm>, 20 March 2008.

28 Note, for example, that there is no discussion of why the administration had decided to invade Iraq, and not Afghanistan, in its pursuit of Al Qaeda-nor is there an examination of the significance of the absence of weapons of mass destruction within the Hussein regime.
} 


\section{THE WAR ON CONCEPTS}

\section{A Way Out? Shakenness as a Starting Point}

What, then, can be done about this state of affairs that continues, in one way or another, to affect most of the planet? The prospect of ending a war whose goal is the eradication of entire concepts - an essentially unattainable objective- seems doubtful. Additionally, the reality of the situation, in spite of the absolutes that are so easily maintained in rhetoric, has become so complicated, both tactically and ethically, that it is difficult ever to foresee an end to the conflict, especially for those not of a mindset determined by a willto-certainty. In such complex circumstances, Patočka may provide us with a starting point from which to act, the best for which he himself could hope in communist Czechoslovakia: the emergence of a solidarity of the shaken.

What might such a solidarity mean, were the Bush administration, and the United States at large, to wake up tomorrow "shaken," unwilling to maintain its security, its particular brand of freedom, its rigid stratification of good and evil, at all costs? The value of such a state is also, it seems, its very weakness: the fact that shakenness does not proffer prescriptions for action. Rather, it is simply, one might say, an existential and, perhaps, political attitude - one that is decisive only about the fact that a person's freedom cannot be contained by a simple desire for security. How, then, could such a posture contribute to changing the United States' war-centered national life?

When shaken, we refuse to accept the black and white answers that society has laid out for us: the certainties of definitions, values, and customs by which we are unquestioningly to live. This outlook, which causes us to "feel inwardly uncomfortable about [our] comfortable position," inherently involves a step back, providing us with a more accurate picture of the assumptions and motivations behind the speech and actions of the everyday. ${ }^{29}$ When in this state, we are not only able to make more truthful diagnoses and criticism of a situation; we also recognize, in spite of diversity of opinion among shaken selves, precisely that we are all shaken. This mutual recognition should mean that we will be unwilling to dismiss each other simply because of those conflicting opinions, and to listen and work together for a state of "agreement in difference." It is the fact that all sides-whether so-called proponents of fear or of freedom - join forces in this new sensibility that is meaningful here. All parties recognize that they must start anew from a point of flexibility, and must make a concerted collective effort if we are ever to move past a state of permanent war or mobilization.

The emergence of this attitude is evident in the continued voicing of questions by U.S., Iraqi, and Afghan populations about the justifications for and the practices involved in the war on terror. The U.S. administration, however, has so far apparently been unwilling to do adopt a similar position. Were it to embrace this stance of humility, however, at least some notable developments may ensue. A shaken administration would, for example, be more willing to reconsider its stance on torture, and not only because of the

${ }^{29}$ Patočka, op cit., 135. 
fact that information elicited under such conditions tends to be unreliable. Rather, a thoughtful examination of the government's practices in this area would consider what effects such methods have on their victims-both the tortured and the torturer-and on populations that witness the execution of torture upon fellow citizens. Moreover, the government may at least begin to accept the reasons why Iraqis, Afghans, and so many others around the world-terrorists, pro-Westerners, and those somewhere in between-might not be so enthusiastic about U.S. involvement in their lives. In addition to the more meaningful dialogue that the U.S. administration might then begin to have with the governments of the countries that it occupies and that it interacts with in general, these developments may lead-admittedly very slowly-to circumstances in which adamant insistence on one's own way is transformed into to a more fruitful method of confronting situations, for all parties involved.

Mere shakenness will bring us no solution to the situation in the Middle East, or elsewhere. Even to achieve such a state is idealistic and difficult to imagine, given the turbulence of the situation and of human nature in general. However, Patočka saw, even in the resigned state of his own nation, the possibility of overcoming what seemed to be a permanently rooted, immovably repressive structure. Although he did not live to see it happen, unbelievably, Czechoslovak shakenness spread, leading to the emergence of a democratic society. In the current, ostensibly hopeless, circumstances, shakenness may be the only place from which to view, much less to work for, a fair and humane solution to the conflict.

Jan Patočka proposed a unique explanation for the continuance of war during his lifetime. We have seen how the elevation of light - of security and certainty - over any aspect of the darkness - the ambiguous and problematic aspects of life- has led to continual warfare and/or permanent military mobilization. In seeking to eliminate all conflict within life, all engagement with the uncertain and the frightening, we paradoxically give it more power over us, and we force ourselves into a continual battle for a final, unrealizable, and absolute peace.

Such developments are evident in the Bush administration's war rhetoric, where the government claims to be fighting, not merely against terrorist actions, but for the elimination of fear, evil, and terror altogether, determined to achieve thereby a final world peace of American-style freedom.

Rather than continue this fight for absolute certainty and for a final victory of one brand of peace, I propose that we examine more closely the possibilities inherent in Patočka's notion of the solidarity of the shaken. For if we are truly to live together as human beings, we must not only allow for differences between us that may sometimes cause uneasiness or fear, but must make a continuous, collective effort to struggle meaningfully with such diversity and to achieve agreement about our common worth, even when such unity may seem impossible to achieve. 


\section{THE WAR ON CONCEPTS}

\section{References}

Andréani, Gilles, "The 'War on Terror': Good Cause, Wrong Concept," in Survival 46 (Winter 2004-05), 31-50.

Ayling, Douglas, "An Analysis of the Rhetoric and the Ideology of the National Security Strategy of the United States of America, 2002," $<$ http://www3.nd.edu/ dayling/content/documentsAcademic/Univ ersity $\% 20$ of $\% 20$ Notre $\% 20$ Dame/Ananalysisoftherhetoricandtheideol ogyoftheNational Security\%81c.pdf>, 21 March 2008.

Bush, George, "Text of Bush Speech on Iraq," in Voice of America $<$ http://www.voanews.com/english/2007-01-11-voa3.cfm>, $\quad 20$ March 2008.

Findlay, Edward F., Caring for the Soul in a Postmodern Age: Politics and Phenomenology in the Thought of Jan Patockea (Albany: State University of New York Press, 2002).

Kay, Joe, "Bush Administration Acknowledges and Defends Use of Torture Technique," in World Socialist Website <http://www.wsws.org/articles 2008/feb2008/tort-f07.shtml>, 21 March 2008.

Lobe, Jim, "Bush Yields to Geneva Convention on Detainees," in Antiwar.com <http://www.antiwar.com/lobe/?articleid=9663>, 21 March 2008.

Millard, Geoff, "Testimony from Winter Soldier Hearings," in Democracynow.org < http://www.democracynow.org/2008/3/18/winter soldier contd us vets active $>, 20$ March 2008.

Negri, Antonio, Time for Revolution, trans. by Matteo Mandarini (New York: Continuum, 2003).

Patočka, Jan, Heretical Essays in the Philosophy of History, trans. by Erazim Kohák and ed. by James Dodd (Chicago: Open Court, 1996).

The White House, "Address to a Joint Session of Congress and the American People," < $\quad$ http://www.whitehouse.gov/news/releases/2001/09/ 20010920-8.html>, April 2008.

The White House, "President Discusses War on Terror at National Endowment for Democracy," < http://www.whitehouse.gov/news/ releases/2005/10/20051006-3.html>, 1 April 2008.

The White House, The National Security Strategy of the United States of America <http://www.whitehouse.gov/nsc/nss.html>, 21 March 2008.

"Torture on Trial," in CommonDreams.org <http://www.commondreams.org/ archive/2008/02/14/7055/>, 2 April 2008.

Voice of America, "Text of Bush Speech on Iraq," in NewsVOA.com

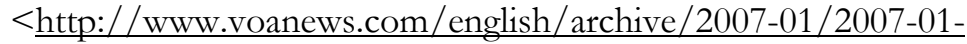
11voa3.cfm?CFID=291042441\&CFTOKEN=39965549> , 1 April 2008.

"White House defends use of waterboarding," in MSNBC.com <http://www.msnbc.msn.com/id/23030663/>, 20 March 2008. 